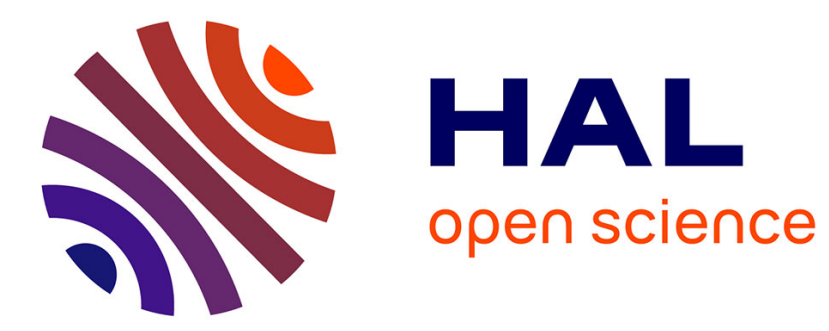

\title{
New data about the consumption of fish from the Alsace Region, France
}

Aurélia Borvon

\section{To cite this version:}

Aurélia Borvon. New data about the consumption of fish from the Alsace Region, France. International Journal of Osteoarchaeology, 2019, 29 (3), pp.407-419. 10.1002/oa.2769 hal-02336766

\section{HAL Id: hal-02336766 https://hal.parisnanterre.fr/hal-02336766}

Submitted on 29 Oct 2019

HAL is a multi-disciplinary open access archive for the deposit and dissemination of scientific research documents, whether they are published or not. The documents may come from teaching and research institutions in France or abroad, or from public or private research centers.
L'archive ouverte pluridisciplinaire HAL, est destinée au dépôt et à la diffusion de documents scientifiques de niveau recherche, publiés ou non, émanant des établissements d'enseignement et de recherche français ou étrangers, des laboratoires publics ou privés. 


\title{
New data about the consumption of fish from the Alsace Region, France
}

\author{
Aurélia Borvon ${ }^{1,2,3}$
}

\author{
${ }^{1}$ Equipe Archéologies Environnementales, \\ UMR 7041 ArScAn, Nanterre, France \\ ${ }^{2}$ Laboratoire d'Anatomie Comparée, Oniris \\ (École Nationale Vétérinaire, Agroalimentaire \\ et de l'Alimentation, Nantes-Atlantique), \\ Nantes, France \\ ${ }^{3}$ Gerom Groupe d'Études Remodelage Osseux \\ et bioMatériaux, Angers, France \\ Correspondence \\ Borvon Aurélia, UMR 7041 ArScAn Equipe \\ Archéologies Environnementales. Nanterre, \\ France. \\ Email: aureliaborvon@gmail.com
}

\begin{abstract}
This study provides an overview of 11 archaeological sites that yielded fish bone remains from the Roman period through medieval to modern contexts. It brings new knowledge about the consumption of fish for the Alsace region. Although the numbers of remains vary greatly, some diachronic comparisons are possible. The majority of the species represented in the assemblages from the inland sites sampled were freshwater fishes, together with a few migratory fishes. Most individuals were small-sized fishes, which may explain the type of structure analysed, for instance, latrines. Two wels catfish vertebrae indicate the presence of this species in France. European marine fishes such as cod and flatfish are very rare, and the importation of marine fish began more recently. However, some herring bones found in the Roman and early medieval period make a straightforward interpretation more difficult.
\end{abstract}

\section{KEYWORDS}

Alsace, Bronze Age, consumption, fish remains, France, Medieval period, Modern period, Roman period

\section{1 | INTRODUCTION}

Until recently, few studies of archaeological fish remains had been undertaken for the Alsace Region in the east of France. The study of 11 archaeological sites changes this, providing new knowledge about fish consumption for this region. It was partly enabled by some recent archaeological excavations (2013-2017), mainly conducted by the French Public Service "Archéologie Alsace." The aim of this paper is to present these new data, the species identified at these sites, and the possible variations, due to temporal change or type of context (pits, latrines, etc.). When necessary, for some species at least, a comparison will be made with data from the literature.

\section{I MATERIAL AND METHODS}

The fish remains are derived from 11 archaeological sites, representing 14 contexts (Table 1 and Figure 1), and are dated from the Roman period through medieval and modern contexts. One site, Erstein, is dated to the Bronze Age, where a pit was discovered. Another site, which dates to the First World War, consists of remains from an excavated hut on a French camp in the Burnhaupt Forest.

Three sites correspond to Roman levels (AD only): Horbourg-Wihr "lotissement Kreutzfeld," Strasbourg "8-20 Route des Romains" and Strasbourg "Place Saint-Thomas." All are urban sites, though the contexts vary. In Horbourg-Wihr, a well and latrines were excavated, which have been dated from the second to third centuries AD. The Strasbourg "8-20 Route des Romains" site yielded fish remains from two different contexts. One is a funeral context with an offering pit and cremations dating from the first century $A D$; the other is a domestic pit dating from the third century AD. The Roman occupation in Strasbourg "Place Saint-Thomas" yielded fish remains from one pit. However, two other occupation phases were also excavated here corresponding to the Early Middle Age and the Central Middle Age. Both pits and latrines yielded medieval fish remains. The Central Middle Age is also documented by the bones discovered at Andlau 


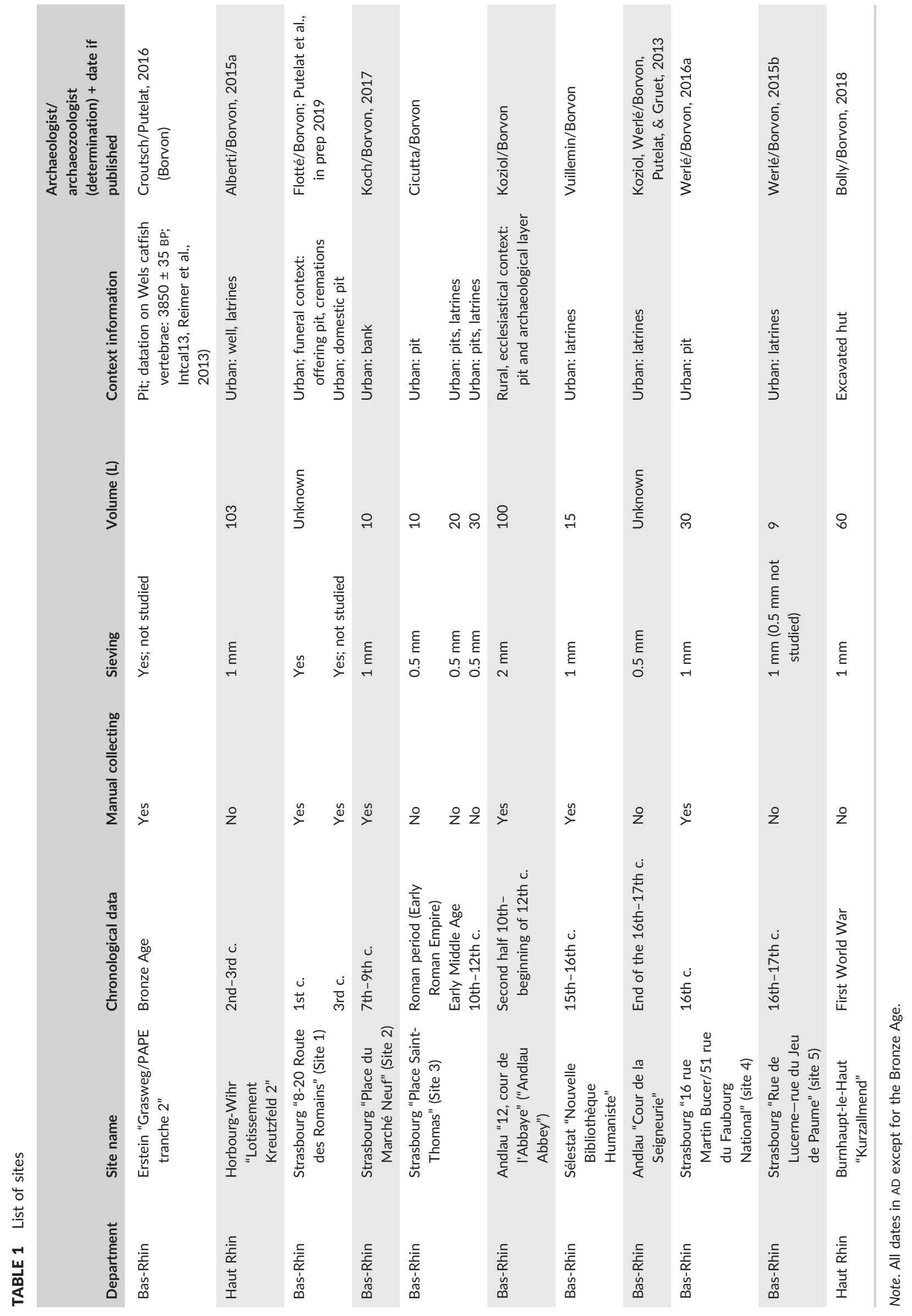



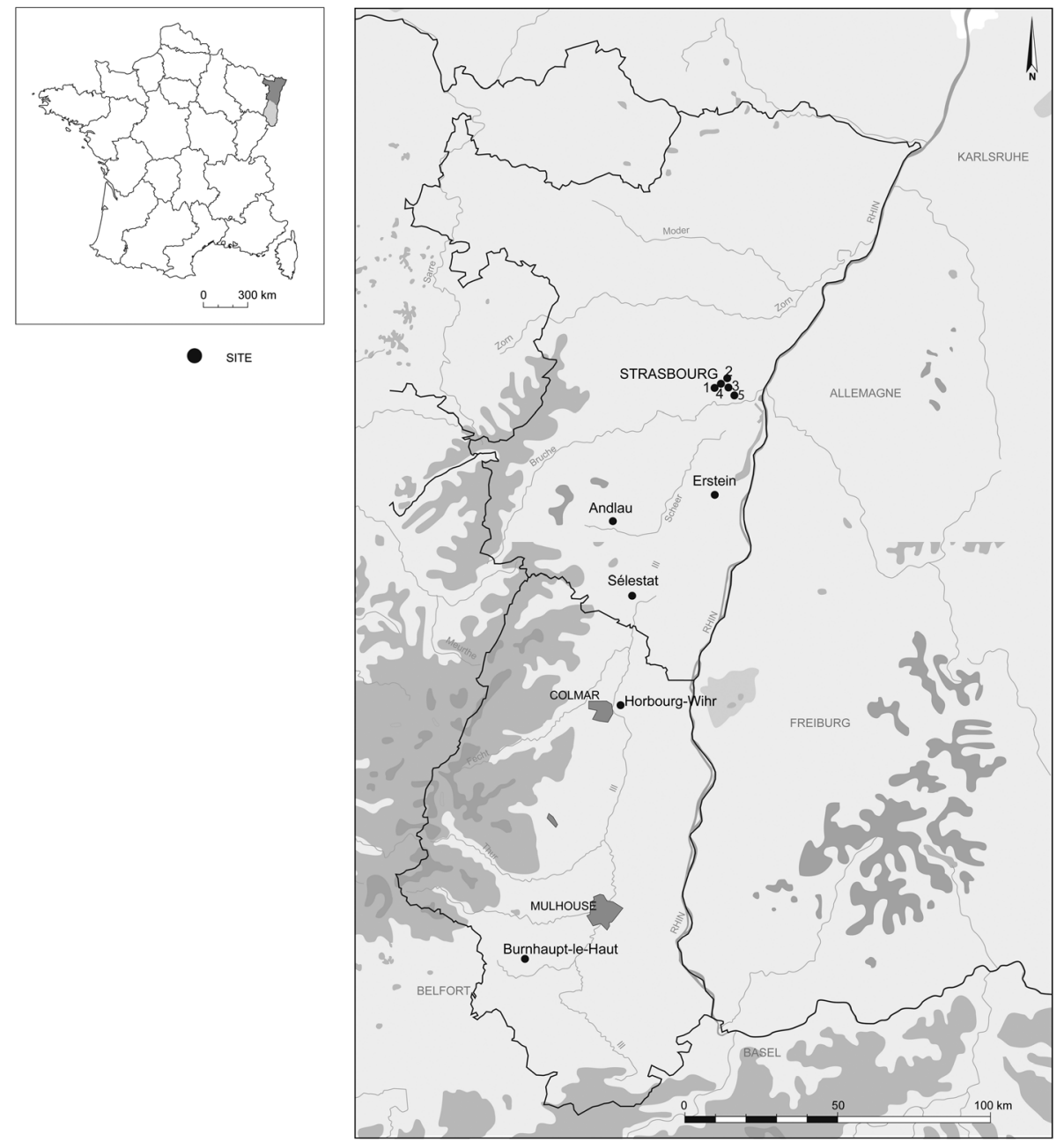

FIGURE 1 Map of the sites (CAD: O. Putelat). For Strasbourg, site numbers are indicated in Table 1

"12 Cour de l'Abbaye" (also called "Andlau Abbey"). This is the only rural site for the period. In this ecclesiastical context, the pit and the archaeological layer provided fish remains. The modern period is documented by four urban sites located in Sélestat, Andlau, and Strasbourg. Fish remains for one of the Strasbourg sites, "16 rue Martin Bucer/51 rue du Faubourg National," derived from a pit whereas the other three assemblages came from latrines.

Latrines are well-represented in this study (Table 1). In these contexts, the fish remains were well-preserved. Some characteristics were the usual indicators of cesspits (e.g., Borvon, 2012: 440, Clavel, 2001b; Smith, 2013; Van Neer \& Lentacker, 1996), such as the presence of surface alterations on bones that are likely the result of passage through the digestive tract, the presence of chewed vertebrae, and the characteristic coloration of bones preserved in the presence of organic matter (Figures 2, 3, and 7). Moreover, physicochemical analyses carried out on the "Place Saint-Thomas" Strasbourg site demonstrated a latrine context due to the presence of sterols of faecal origin (Cicutta, unpublished data). Similarly, the almost systematic discovery of detritivores, such as woodlice, and of necrophages/ coprophages, such as diptera larvae or pupae-attracted by organic matter essential for their biological life cycle-is also a good indicator of the presence of excrement.
Due to the discovery of these cesspits during excavation, the archaeologists collected bulk samples of sediment in order to recover the broad range of micro remains (e.g. seeds) and fish remains. In the "Archéologie Alsace" Service, sediment sampling and wet sieving are routinely undertaken. Usually a volume of $10 \mathrm{~L}$ of sediment was taken per structure or level. Two larger volumes $(50 \mathrm{~L})$ were sieved for two structures in the Abbey of Andlau. The mesh size generally used was 0.5 or $1 \mathrm{~mm}$ (Table 1). Sieving was undertaken at all sites except at the Erstein (Bronze Age) and Strasbourg "Route des Romains" (Roman period) sites. At some sites, fish remains were also hand collected (Table 1).

Identification of the fish remains was undertaken using general manuals and identification keys (Cannon, 1987; Le Gall, 1984; Lepiksaar, 1994; Libois, Hallet-Libois \& Rosoux, 1987; Libois \& Hallet-Libois, 1988; Radu, 2005), as well as through side-by-side comparison with specimens in the reference collection of the Comparative Anatomy Lab of ONIRIS (Nantes Atlantic College of Veterinary Medicine, Food Science and Engineering, France). For each taxon, two quantification parameters were used: number of identified specimens (NISP) and minimum number of individuals. The latter corresponds to the highest minimum number of anatomical elements. Additional individuals can be counted when different sizes are 
(a)
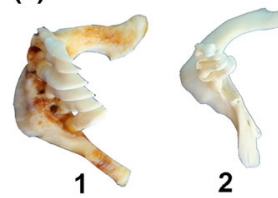

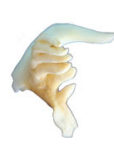

4

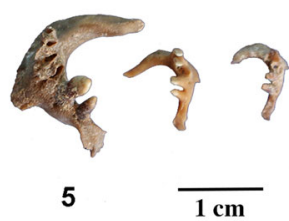

$\overline{1 \mathrm{~cm}}$

(b)

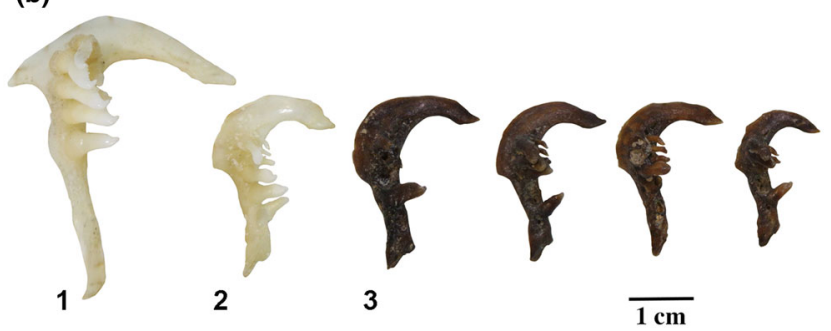

FIGURE 2 Pharyngeal bones and teeth of cyprinids. (a) with one row of teeth: 1: nase, Chondrostoma nasus (reference collection ONIRIS, $\mathrm{TL}=28.8 \mathrm{~cm}$ ); 2 : tench, Tinca tinca (reference collection ONIRIS, $\mathrm{TL}=25 \mathrm{~cm}$ ); 3: bream, Abramis brama (reference collection ONIRIS, $\mathrm{TL}=24 \mathrm{~cm}$ ); 4: roach, Rutilus rutilus (reference collection ONIRIS, $\mathrm{TL}=22 \mathrm{~cm}$ ); 5: roach, $R$. rutilus (Sélestat "Nouvelle Bibliothèque humaniste," 15th-16th century AD); (b) with two row of teeth: 1 : bleak, Alburnus alburnus (reference collection ONIRIS, TL = $15.8 \mathrm{~cm}$ ); 2 : gudgeon, Gobio gobio (reference collection ONIRIS, TL = $9.5 \mathrm{~cm}$ ); 3 : gudgeon (Strasbourg "Place Saint-Thomas," Early Middle Age; photographs: A. Borvon) [Colour figure can be viewed at wileyonlinelibrary.com]

estimated. In this study, fish lengths (total length [TL]) were largely estimated by direct comparison with reference specimens of known $\mathrm{TL}$ due to the low number of feasible measurements and/or lack of suitable regression equations in the literature. Age estimation was based on the count of the arrested growth lines on a few vertebrae.

\section{3 | RESULTS}

\section{1 | General presentation of the corpus}

A total of 6,427 bones were studied (Table 2). In addition, 2,885 scales were counted. Scales were particularly numerous in the Abbey of Andlau with more than 2,000 fragments. A few of them were ctenoid and belonged to European perch (Perca fluviatilis). Among the samples analysed, 2,739 bones were identified.

The number of remains varied between sites, which may be partly explained by the variety of contexts represented and differences of preservation. The very good preservation in latrines explains why they generally delivered the largest assemblages (Table 2). The same remark is valid for pits. The funeral context of Strasbourg "Route des Romains" for the Roman period was also rich in fish remains. In all of these contexts, the NISP ranged from 81 to 561 (Table 2). Three others, Erstein from the Bronze Age, Strasbourg "Route des Romains" from the third century $A D$, and Burnhaupt-le-Haut from the First World War, delivered only very few remains, one, three, and nine, respectively (Table 2). The Roman context of the "Place Saint-Thomas"

in Strasbourg yielded only one identifiable fish bone, despite having relatively numerous remains.

Various species were identified, totalling 17 different taxa. Mostly freshwater species were present. Migratory fish and marine species were also identified. Each taxon was more or less frequent, from only 1 to 10 contexts.

\section{2 | Species present}

Cyprinids were present in almost all assemblages, excluding the oldest and youngest sites (Table 2). Cyprinid bones were the most numerous component of assemblages with the exception of the latrines of Strasbourg's "Place Saint-Thomas" for the Central Middle Age. In general, they were also the most abundant in terms of minimum number of individuals. In the latrine contexts, they were sometimes particularly frequent, for instance, the Early Middle Age context from the site of "Place Saint-Thomas" with an estimated 45 individuals, or in "Rue de Lucerne-Rue du Jeu de Paume" in Strasbourg for the Modern period, with 57 fish (Table 3).

Some of their bones could be identified to the species level (Table 3), usually through the analyses of the pharyngeal bones and teeth (Libois \& Hallet-Libois, 1988; Figure 2). Within the group of species with one row of teeth, two were identified among four potentials, roach (Rutilus rutilus) and common bream (Abramis brama). The former was present in the majority of medieval and modern contexts (Table 3) ; the latter was rarer. The majority of the pharyngeal and tooth bones discovered exhibited two rows of teeth. Many species are possible candidates as they are morphologically very similar. In general, they could not be differentiated. The only exception is the gudgeon (Gobio gobio), whose morphology is slightly different (Figure 2). It was one of the most frequently recovered species (five contexts). Sometimes dentaries (Libois \& Hallet-Libois, 1988) or basioccipitals (Le Gall, 1984) were also used for species identification; for instance, a few bleak (Alburnus alburnus) or chub (Squalius cephalus) individuals were identified based on these elements. The two possible species with three rows of teeth were identified: common carp (Cyprinus carpio) appeared only in the 15th-17th century AD contexts (Table 3); the common barbel (Barbus barbus) was mostly present in the Roman offering pit context (Strasbourg "Route des Romains"). The seven individuals from the latter site are represented by their near-complete vertebral column. The morphology of the second vertebrae enabled species identification. These fishes had an estimated TL between 20 and $30 \mathrm{~cm}$. Generally speaking, in the majority of cases, the estimated $\mathrm{TL}$ was very small for cyprinids, especially those recovered from the latrines, where most of them were $<15 \mathrm{~cm}$ in TL. For example, among the 57 fish analysed for "Rue de Lucerne-Rue du Jeu de Paume" (Strasbourg, Modern period), only six were $>10 \mathrm{~cm}$ in TL. In contexts other than latrines, larger individuals were sometimes present. At Andlau Abbey, for example, two fish had a TL of 40 and $50 \mathrm{~cm}$; seven were between 10 and $20 \mathrm{~cm}$.

Small species of cyprinids or juveniles of larger cyprinids (in the case of the latrines) were frequently present with some other smaller 
(a)
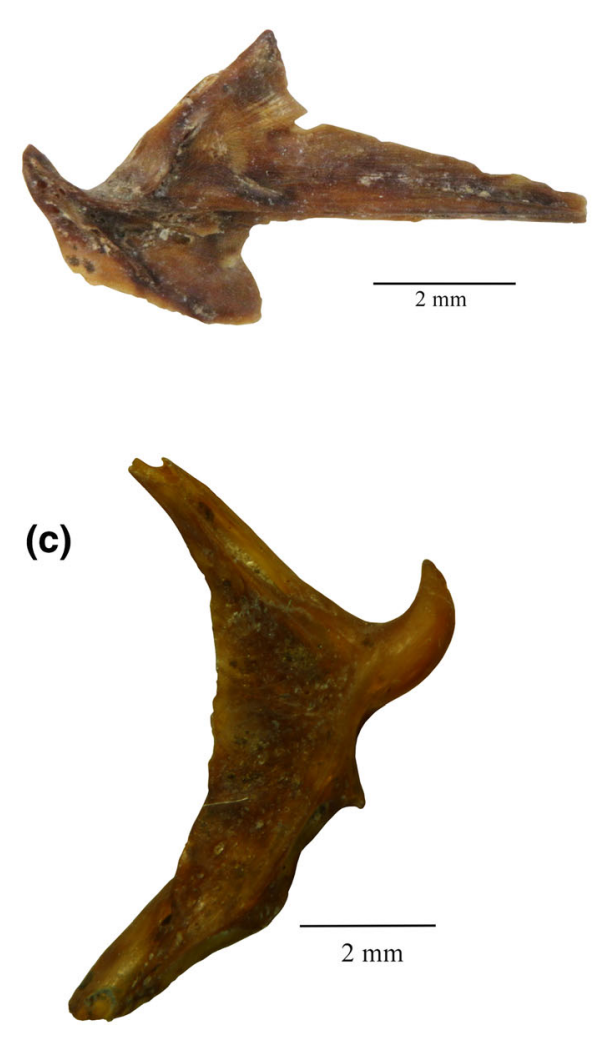

(b)

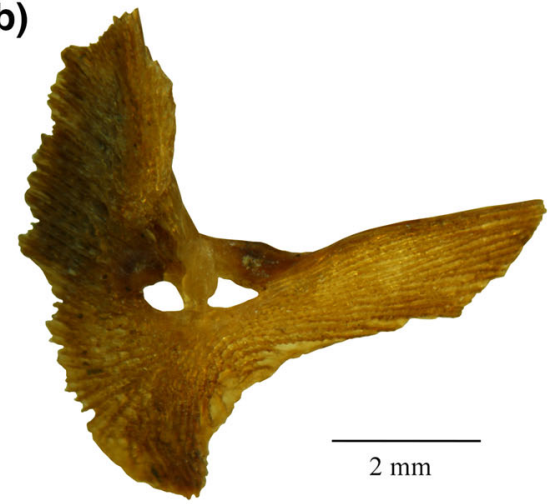

(d)

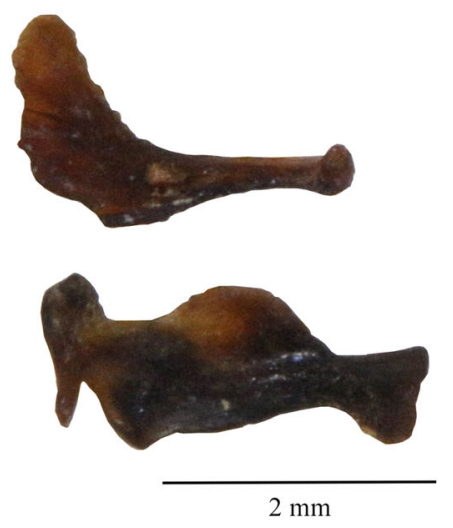

FIGURE 3 Bones from different species. (a) articular of burbot (Sélestat "Nouvelle Bibliothèque Humaniste," 15th-16th century AD); (b) basipterygium of three-spined stickleback (Strasbourg "Place Saint-Thomas," 10th-12th century AD); (c) preopercular of bullhead (Strasbourg "Place Saint-Thomas," 10th-12th century AD); (d) dentary and premaxillary of stone loach (Strasbourg "Place Saint-Thomas," 10th-12th century AD; photographs: A. Borvon) [Colour figure can be viewed at wileyonlinelibrary.com]

species. Three of them were very frequent (Table 2), three-spined stickleback (Gasterosteus aculeatus), bullhead (Cottus sp.), and loach (Figure 3). For the latter, when identification was possible, the archaeological specimens corresponded well to stone loach (Barbatula barbatula). Sometimes, bones of these small species were very numerous, for instance, the latrines of Strasbourg's "Place Saint-Thomas" dating to the 10th-12th century AD, which delivered 32 loaches and 17 sticklebacks. The latter was also very abundant in Strasbourg's "Rue de Lucerne-Rue du Jeu de Paume" with 30 individuals.

Pike (Esox lucius) bones were frequent (Table 2). They were present in nine contexts from seven sites but were not numerous at each site, with often $<10$ bones. The only exception was at Andlau Abbey, with just less than 100 bones. The eight individuals counted on this site were between 27 and $53 \mathrm{~cm}$ in TL (cleithrum and dentary; De Grossi Mazzorin \& Frezza, 2000; Enghoff, 1994). Smaller specimens were found in different contexts, especially latrines. Some individuals were relatively large, for example, Strasbourg's "Route des Romains" (TL $~ 70 \mathrm{~cm}$ ) or in Andlau "Cour de la Seigneurie" (TL $60 \mathrm{~cm})$. Some pike bones have cut marks (Figure 4).

In much the same way as pike, burbot (Lota lota) was not represented by many bones at each site, in general $<10$, but it was present at many sites (seven sites for eight contexts). Very few bones belonged to the perch, in addition to a few ctenoid scales mentioned before. A vertebra of wels catfish (Silurus glanis; Figure 5) from the
Bronze Age site of Erstein is the oldest example of this fish discovered in Alsace. This species is also recorded by one vertebra at the Roman period from the "Route des Romains" site in Strasbourg. This is one of the only species discovered without sieving due to the size of the element. The estimated TL of the fish deduced from the size of the vertebrae was $>2 \mathrm{~m}$ for the two sites. These fish would have been more than 20 years old.

Remains of grayling (Thymallus thymallus) were only present in two assemblages: seven bones for the Central Middle Age context of Strasbourg's "Place Saint-Thomas" and one from Andlau "Cour de l'Abbaye" (Table 2). Salmonid remains were also infrequent and were present at six sites throughout the chronological sequence. Identification to either trout or salmon is complex because of the morphoanatomical similarity between these two species of the genus Salmo, especially vertebrae (Borvon et al., 2018; Desse-Berset, 1994; Guillaud, Cornette \& Béarez, 2016; Le Gall, 1984). If preserved, aDNA analysis would perhaps distinguish between them (Oueslati, 2017). Salmon may be present at the "Route des Romains" site because the estimated TL of some individuals was large, for example, $>70 \mathrm{~cm}$ at Strasbourg's "Route des Romains" or "Rue Martin Bucer." The estimated TL, between 20 and $30 \mathrm{~cm}$, at Strasbourg's "Place du Marché Neuf," Andlau Abbey and Andlau "Cour de la Seigneurie" indicate trout rather than salmon, the latter being theoretically at sea after achieving this length (Porcher \& Baglinière, 2011). The morphology of the vomer 


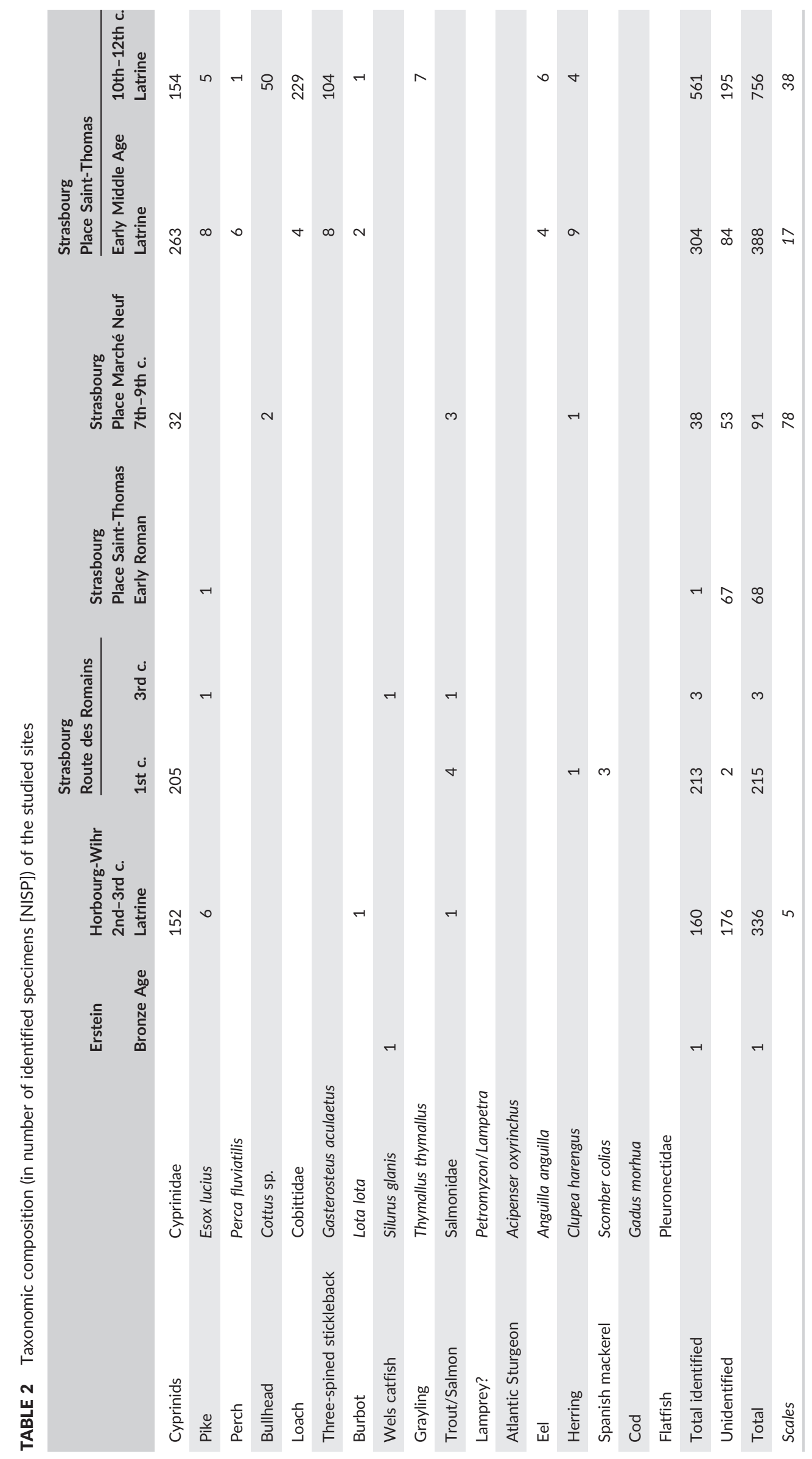



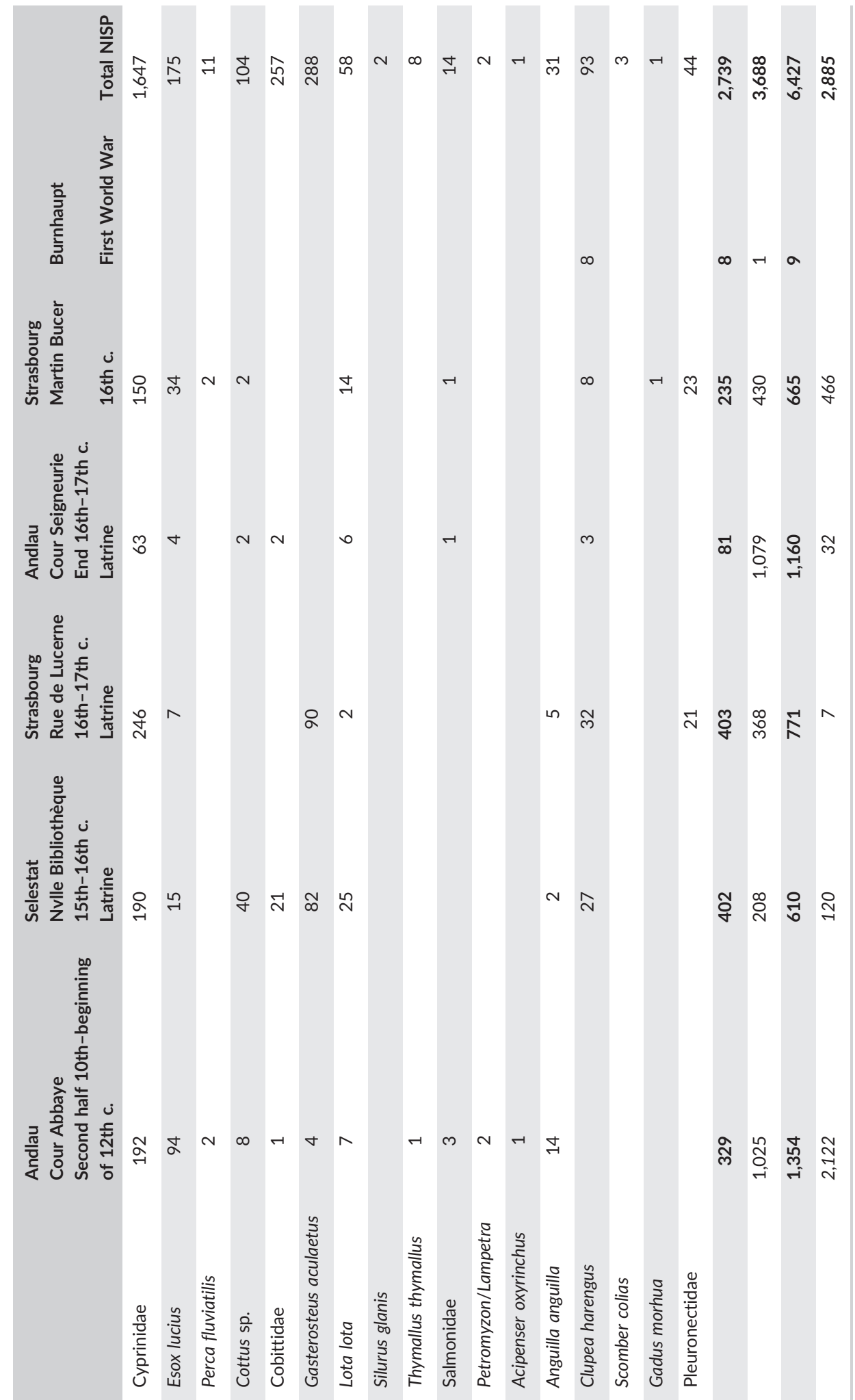

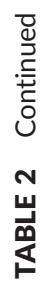

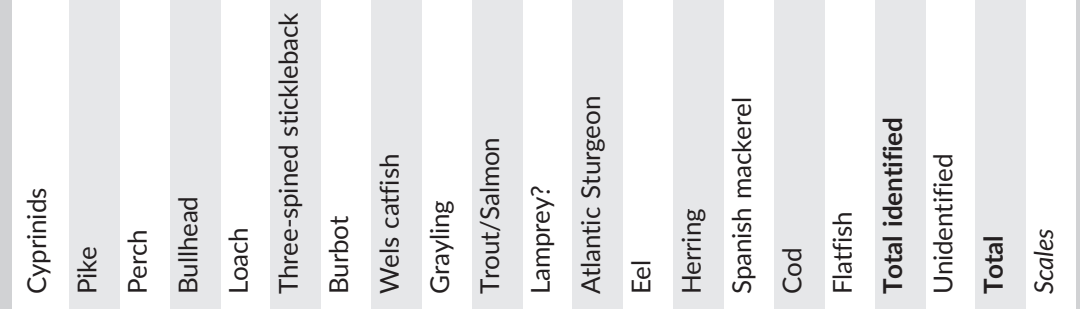




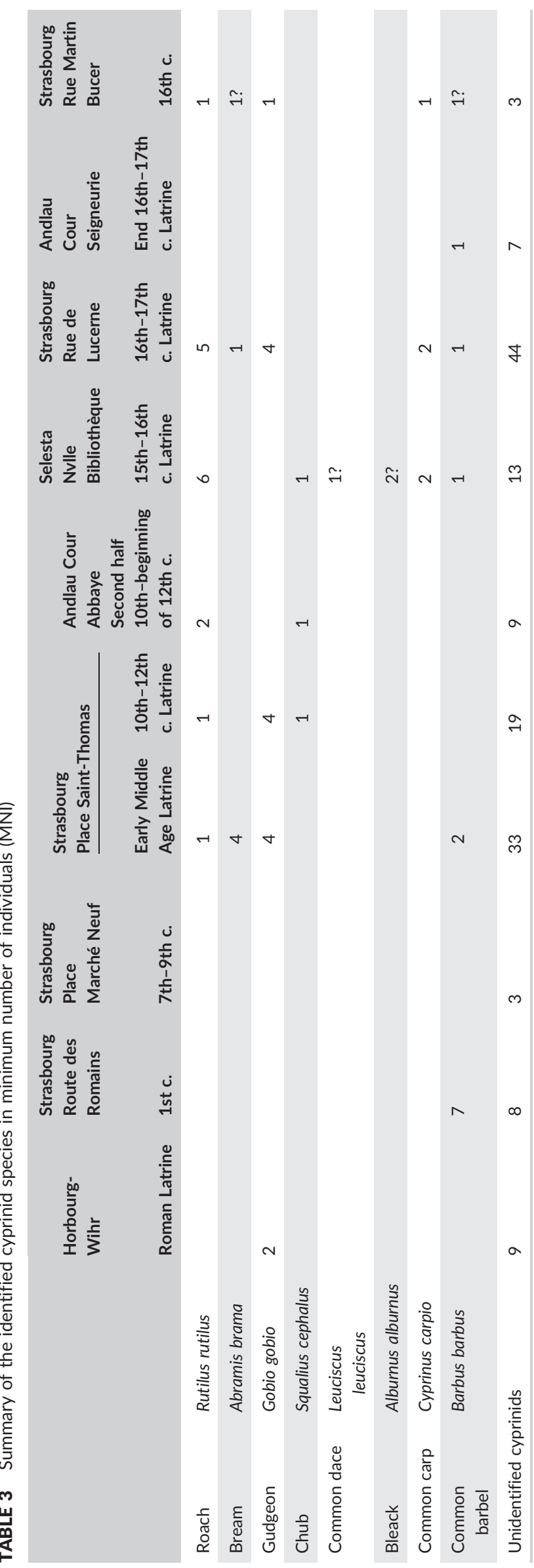

(a)

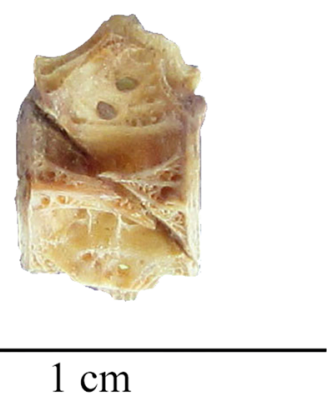

(b)

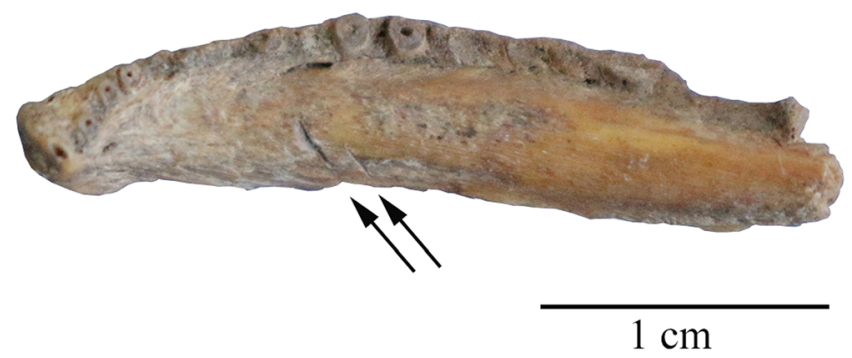

FIGURE 4 Cut marks on (a) caudal vertebrae of pleuronectid (Strasbourg "Rue Martin Bucer/Rue du Faubourg National," 16th17th century $A D$ ) and (b) pike dentary (Andlau "Cour de l'Abbaye," second half of 10th-beginning of 12th century AD; photographs: $A$. Borvon) [Colour figure can be viewed at wileyonlinelibrary.com]

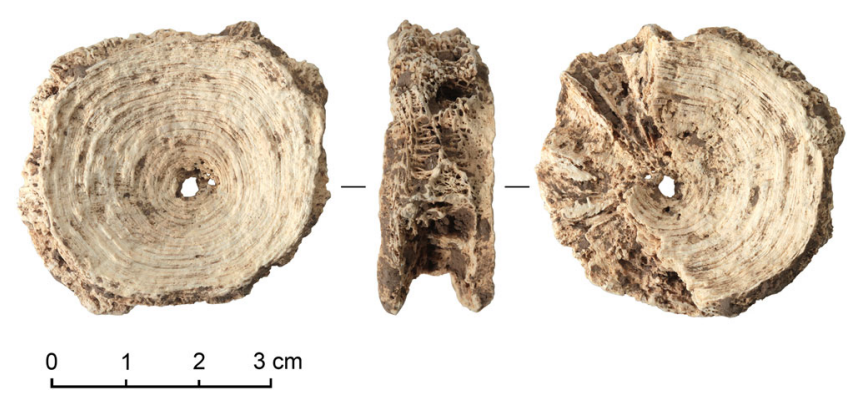

FIGURE 5 Vertebra of wels catfish from the Bronze Age site of Erstein (photograph: I. Dechanez-Clerc, Archéologie Alsace) [Colour figure can be viewed at wileyonlinelibrary.com]

discovered at Andlau "Cour de la Seigneurie" was similar to trout (Spillmann, 1989).

In addition to the many freshwater species, some migratory species were also present, including European eel (Anguilla anguilla) and sturgeon (Acipenser sp.). Eel remains were infrequent, being only identified in five medieval and modern contexts. Similarly, only one sturgeon remain was present, a cleithrum from the Andlau Abbey (Figure 6). It was identified as Atlantic sturgeon (Acipenser oxyrinchus) from the appearance of the external bone surfaces (Desse-Berset, 2011a, 2011b). Cut marks were also present. The TL of the specimen was probably $>1.5 \mathrm{~m}$. Two denticles discovered in the Andlau Abbey could belong to lamprey. Only these horny teeth forming a sucker at the mouth preserve. The two possible species are sea lamprey (Petromyzon marinus) and river lamprey (Lampetra fluviatilis; Sabatié \& Baglinière, 2001). 
(a)

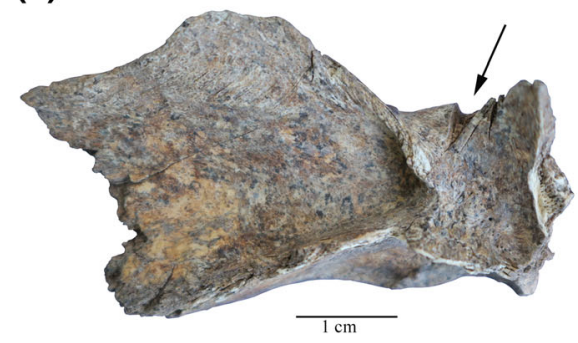

(b)

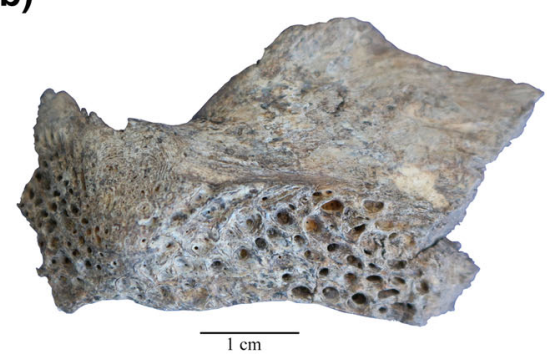

FIGURE 6 Cleithrum of Atlantic sturgeon (species identification: N. Desse-Berset, Cepam); (a) medial and (b) lateral view. It presents cuts marks on its medial face (Andlau "Cour de l'Abbaye," second half of the 10th-beginning of the 12th century AD; photograph: I. Dechanez-Clerc, Archéologie Alsace) [Colour figure can be viewed at wileyonlinelibrary.com]

(a)

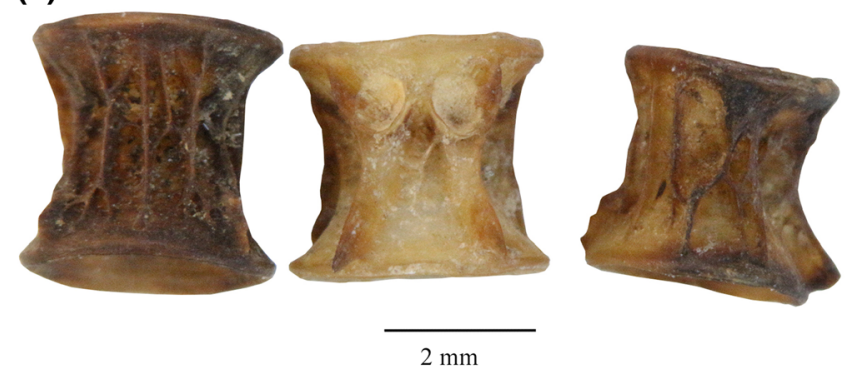

(b)
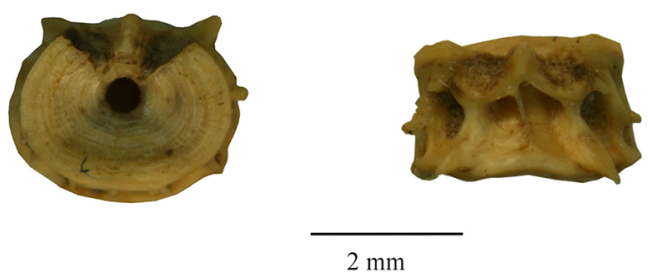

FIGURE 7 Herring vertebrae: (a) thoracic vertebrae from Sélestat "Nouvelle Bibliothèque Humaniste," 15th-16th century AD; (b) second vertebra from Strasbourg "Route des Romains," first century $A D$, cranial and dorsal views (photographs: A. Borvon) [Colour figure can be viewed at wileyonlinelibrary.com]

Only four strictly marine species were identified. Very few Spanish mackerel (Scomber colias) vertebrae were present in a Roman funeral offering context from Strasbourg "Route des Romains," dating to the first century AD. A cod vertebra fragment was identified in the 16th-17th century AD context in Strasbourg's "Rue Martin Bucer." It belonged to an individual $>1 \mathrm{~m}$ in TL. Remains of flatfish (pleuronectidae) were recovered from two modern sites in Strasbourg (16th-17th century $A D$ ). When species identification was possible, these remains belonged to the European plaice (Pleuronectes platessa; Wouters, Muylaert, \& Van Neer, 2007). Mainly vertebrae were recovered and sometimes they exhibited cut marks (Figure 4).

Remains of Atlantic herring (Clupea harengus) were represented at all medieval and modern contexts (Table 2) except at Andlau Abbey. They were only relatively numerous at two modern sites, Sélestat "Nouvelle Bibliothèque Humaniste" and Strasbourg "Rue de LucerneRue du Jeu de Paume." For the First World War context, the eight vertebrae identified belonged to this species. One single vertebra was discovered for the Roman period (Table 2). Its morphology (Figure 7) rules out other species from the same family such as shad and pilchard. The estimated TL of $\sim 25 \mathrm{~cm}$ also excludes sprat. On all sites, Atlantic herring was mostly represented by vertebrae. Estimated TLS ranged between 20 and $30 \mathrm{~cm}$. The smallest were often recovered in latrines.

All these strictly marine species were probably imported because of the distance from the sea. Situated along the Rhine River, Strasbourg is located $750 \mathrm{~km}$ from the North Sea.

\section{4 | DISCUSSION}

Mainly Roman, medieval and modern periods are considered for discussion because few data are available for the other time periods. For the First World War, the few remains available do not enable us to explore the consumption of fish extensively. However, the presence of herring demonstrates that these fish had not been locally caught and were probably imported as preserved fish. The oldest specimen from the 11 sites was a vertebra of a wels catfish. Remains of this species have rarely been identified in France (for a recent synthesis see Putelat, Borvon \& Guizard, in prep. 2019), as well as the adjacent countries of Switzerland and Belgium (Ambros, 1990; Hüster Plogmann, 2004; Hüster Plogmann \& Häberle, 2017; Jacquat \& Studer, 1999; Studer, 2003; Van Neer \& Ervynck, 2004, 2009). Its presence in the assemblage from the Bronze Age site of Erstein is the earliest example in France. A vertebra was also found in a Roman level. So these discoveries provide new data concerning the distribution of wels catfish to the west of its recognized range, that is the Rhine River (Proteau, Schlumberger \& Élie, 2008; Schlumberger, Sagliocco \& Proteau, 2001).

\section{1 | Food refuse and type of contexts}

Except for Strasbourg "Route des Romains," which consisted of funeral offerings, the bones studied on the different sites correspond to fish consumption. For the most part, the bones of different taxa likely come from species that had been eaten, even if their consumption is more difficult to demonstrate than that of mammals or birds, especially because of the absence of butchery marks. On some sites, 
however, cut marks were regularly identified (Figures 4 and 6). The remains were also collected from waste, identified as being of food origin, considering the kinds of mammal and bird remains present. Similarly, the presence of strictly marine species, necessarily imported due to the considerable distance from the sea, excludes an origin other than anthropic. These latter species are often represented by only a few bones, which are mostly vertebrae. This observation, paired with distance from the sea, implies the presence of preserved fish (e.g., Clavel, 2001a; Van Neer \& Pieters, 1997), which infers preparation for transport (smoking, drying and salting).

On five sites, the characteristics of the fish bone assemblages corresponded to a latrine-type context that provided very good conditions of preservation. The presence of excremental releases enables us to explain the small general size of the remains and consequently the observed TLs of the individuals. In the majority of these assemblages, there were very few specimens $>15 \mathrm{~cm}$. These small fish were essentially juvenile cyprinids or smaller species of this family and smaller species of fish, such as loach, bullhead, or stickleback. Furthermore, they were often very numerous in number of individuals. For instance, 25 cyprinids, seven bullheads, 32 loaches, and 17 sticklebacks were identified in the latrines from Strasbourg's "Place SaintThomas." In comparison, the other types of contexts yielded only a few individuals for each species, generally <10. Strasbourg's "Martin Bucer" pit comprised only eight cyprinids, three pikes, two burbots, and one individual for each of the other species. Although small fish were also present, the estimated TLs were generally larger, as at Andlau Abbey with two cyprinids of 40 and $50 \mathrm{~cm}$ in TL. The amount of scales on this site and in Strasbourg's "Martin Bucer" were also very different than in the latrine contexts. On these two sites, freshwater fish bones most likely are butchery or consumption waste rather than ingested fish like in the latrines.

\section{2 | Fish remains during the Roman period}

The identified species for the Roman period were mainly freshwater fish, which corresponds with previous studies for the region (e.g., Ginella, Hüster Plogmann \& Schibler, 2009; Hüster Plogmann, 1999, 2003). The two contexts with numerous fish bones are, however, rather different in our study. One corresponds directly to fish consumption, a latrine (Horbourg-Wihr, second and third century $\mathrm{AD})$ with the characteristics described above: mainly small and numerous fishes. It yielded almost exclusively cyprinids. The other corresponds to a funeral context with an offering pit and cremations (Strasbourg "Route des Romains," first century AD). Cyprinids were also the most numerous. They were deposited more or less whole in cremations, whereas the two large-sized salmonids were deposited as steaks in the offering pit. The few vertebrae of the Spanish mackerel were also found in cremations. Commonly identified in Roman period assemblages, this species was imported from the Mediterranean, prepared for transport in the form of salted products (salsamenta; Desse-Berset \& Desse, 2000; Hüster-Plogmann, 2006, p. 229; Van Neer, Ervynck \& Monsieur, 2010). The difference in the origin of the deposit could explain that, contrary to all cyprinid bones, mackerel vertebrae were not burnt. Importation of prepared fish must be assumed for the single herring vertebra too, despite its different geographical origin, that is Northern Europe. Its size is more suggestive of salted fish rather than fish sauce. Its presence here appears to be one of the earliest known so far (Van Neer et al., 2010). The large quantities of fish remains for the funeral site are also unusual when compared with data published elsewhere (Oueslati, 2013; Putelat, 2018).

\subsection{Fish consumption during medieval and modern periods}

For the medieval period, the species encountered were generally those classically identified on medieval sites far from the sea (Borvon, 2012; Clavel, 2001a; Galik, Haidvogl, Bartosiewicz, Guti \& Jungwirth, 2015; Hüster-Plogmann, 2007; Van Neer \& Ervynck, 1994). The lamprey is of special note, being very rarely found in archaeological contexts due to the teeth being the only element that normally survive. To our knowledge, its presence is attested in only a few medieval sites, including Montsoreau dating to the 11th century $A D$ in France (Borvon, unpublished data) and York, Great Britain (Jones, 1988).

The common pattern is the dominance of freshwater fish species and particularly cyprinids. Although the majority were autochthonous, one was introduced, the common carp. In general, its remains are scarce, being only present in the 15th-17th century AD levels (Sélestat "Nouvelle Bibliothèque," Strasbourg "Rue de Lucerne," and "Rue Martin Bucer"), which is later than the presumed date of introduction into France and Belgium. Archaeologically, their bones are in fact not found before the 13th century $A D$ and only in high social level contexts at the beginning (Clavel, 2001a; Van Neer \& Ervynck, 1994). This Alsatian find corresponds to the increase of this species' discovery (Clavel, 2001a).

Despite the dominance of cyprinids, a large range of species (between seven and nine fish taxa) were present at all sites, with the exception of the early medieval Strasbourg site ("Place du Marché Neuf"), which supplied only a few identified remains. Cyprinids were often accompanied by pike, burbot, and herring, albeit in varying amounts. The other species were generally more anecdotal in NISP and are not necessarily present at all the sites (e.g., eel and perch). Numerous sticklebacks were present at Strasbourg's "Rue de Lucerne-Rue du Jeu de Paume," but as has already been stated, this is partly due to context, that is a latrine.

The list of species is thus often relatively long, although shorter than on some very privileged sites, particularly in the Paris region (Borvon, 2016b; Clavel, 2001a; Desse \& Desse-Berset, 1992). On several sites the presence of marine species and salmon, for example, Strasbourg's "Rue de Lucerne-Rue du Jeu de Paume," may indicate that the consumers were wealthy. It is clearer at Andlau Abbey for the 10th-12th centuries AD where the presence of certain prestigious species such as sturgeon, the probable lamprey, and far more pike than in other assemblages clearly indicates a high social status, which 
is otherwise indicated by other archaeozoological data (Koziol, unpublished data).

The presence of herring is not surprising during the late medieval and modern periods. Its presence, however, appears to be relatively early for the medieval period. It was relatively unobtrusive on inland sites before its consumption steadily increased (like the carp) from the 13th century $A D$ to meet the growing demand for fish, especially in urban areas (Clavel, 2001a; Van Neer \& Ervynck, 2003).

\section{5 | CONCLUSION}

This study of fish remains provides new data for Alsace, a region that has hitherto hardly been studied in regard to ichthyoarchaeological analysis. Fish bone material covers mostly the Roman period through medieval to modern contexts. The only bone from the Bronze Age is a wels catfish vertebra, which is a further testimony to the presence of this species in France. Except for a Roman site, which delivered funeral offerings, the fish remains corresponded to food consumption refuse. Because of the inland location, the majority of the species represented in the assemblages were freshwater fish. Their diversity is high, and the data underline the importance of young or small fish for food, particularly visible in the analysed latrine contexts. However, sieving has probably increased the relative numbers of these small remains compared with the other analysed contexts. In general, marine fish were infrequent, probably due to the distance from the coast. The occurrence of herring in Roman times is interesting to report, as well as its regular mention in medieval and modern assemblages. Although investigations are ongoing, a larger synthesis should be undertaken in the future to include ichthyoarchaeological data from nearby regions in Germany, Switzerland, and Belgium.

\section{ACKNOWLEDGEMENTS}

Special thanks to the archaeologists who took samples for sieving during the excavations (Archéologie Alsace: G. Alberti, A. Bolly, C. Croutsch, P. Flotté, J. Koch, A. Koziol, A. Vuillemin, M. Werlé; Inrap: $\mathrm{H}$. Cicutta) and to O. Putelat (zooarchaeologist, Archéologie Alsace) who initiated all these ichthyological studies. Acknowledgements also to sediment sorters, mostly O. Putelat, occasionally helped by $\mathrm{E}$. Guthmann (student, Strasbourg University), and E. Bonnaire (carpologist, Archéologie Alsace). Thank you to the three reviewers; their remarks have resulted in important improvements.

\section{ORCID}

Aurélia Borvon (D) https://orcid.org/0000-0002-7432-2518

\section{REFERENCES}

Ambros, C. (1990). Vogel- und Fischreste aus dem römischen Avenches. In H. R. Stampfli, H. Spycher, J. Sedlmeier, \& J. Schibler (Eds.), Festschrift für Hans R. Stampfli (pp. 13-18). Bâle: Helbing and Lichtenhahn.

Borvon, A. (2012). Acquisition des ressources animales, alimentation carnée et distinction sociale en Anjou de la fin du $\mathrm{X}^{\mathrm{e}}$ au début du XII siècle. Étude archéozoologique du site de Montsoreau (Maine-etLoire). Thèse de doctorat, Université Paris 1 Panthéon-Sorbonne, Paris.

Borvon, A. (2015a). Étude des vestiges ichtyologiques. In G. Alberti (Ed.), Horbourg-Wihr, Haut-Rhin. Lotissement Kreuzfeld est 2. Opération 5490. Un quartier périphérique de l'agglomération antique. Volume 3.2 Analyses, études spécialisées, Rapport de fouille préventive (pp. 79-85). Sélestat: Pôle d'Archéologie Interdépartemental Rhénan.

Borvon, A. (2015b). Les restes ichthyologiques. In M. Werlé (Ed.), Strasbourg, Bas-Rhin. Rue de Lucerne-Rue du Jeu-de-Paume. Rapport de fouille préventive. Volume 1. Le système défensif primitif et le processus d'urbanisation d'un secteur du faubourg de la Krutenau du Moyen Âge à nos jours (p. 274, 277, 294-297, 304-308). Sélestat: Pôle d'Archéologie Interdépartemental Rhénan.

Borvon, A. (2016a). Les restes ichthyologiques. In M. Werlé (Ed.), Strasbourg, Bas-Rhin. 16 rue Martin Bucer-51 rue du Faubourg National. Le processus d'urbanisation d'un site dans le faubourg ouest, près de l'église Sainte-Aurélie, de l'Antiquité à nos jours. Rapport de fouille préventive (pp. 293-298). Sélestat: Pôle d'Archéologie Interdépartemental Rhénan.

Borvon, A. (2016b). Étude des restes ichthyologiques et des restes d'Écrevisses (Crustacé Décapode d'eau douce) de la zone attenante à la cour carrée du Louvre. In K. Ducat (Ed.), Paris (75)-Musée du Louvre, Cour carrée (Jardin Raffet). Neuf cents ans de vestiges entre le Palais du Louvre et la Seine. Rapport final d'opération archéologique (fouille préventive) (pp. 285-295). Paris: Éveha, SRA Île-de-France.

Borvon, A. (2017). L'ichtyofaune du remblai 1032. In J. Koch (Ed.), Strasbourg, Bas-Rhin. Place du Marché Neuf. Une occupation de la fin de I'Antiquité à l'époque moderne. Opération 6217. Rapport de fouille préventive (pp. 43-44, 92-93, 107). Sélestat: Archéologie Alsace.

Borvon, A. (2018). L'ichtyofaune. In A. Bolly (Ed.), Reiningue, Haut-Rhin " Vorwald et Heiden ", Burnhaupt-le-Haut, Haut-Rhin "Kurzallmend", Schweighouse-Thann, Haut-Rhin "Einnehmersberg et Kleineweiheracker ». La ligne de front allemande et française de la Première guerre Mondiale. Rapport de fouille préventive, Construction de la LGV Rhin-Rhône (p. 261). Sélestat: Archéologie Alsace.

Borvon, A., Bridault, A., Biton, R., Rabinovich, R., Prevost, M., Khalaily, H., \& Valla, F. (2018). Finding of trout (Salmo cf. trutta) in the Northern Jordan Valley (Israel) at the end of the Pleistocene: preliminary results. Journal of Archaeological Science: Reports, 18, 59-64. https://doi.org/ 10.1016/j.jasrep.2018.01.008

Borvon, A., Putelat, O., \& Gruet, Y. (2013). L'alimentation carnée. In M. Seiller, \& M. Werlé (Eds.), La Seigneurie d'Andlau. Un hôtel aristocratique de la fin du XVle s. dans le vignoble alsacien (pp. 105-111, 135-136). Barr et Obernai: Société d'histoire et d'archéologie de Dambach.

Cannon, D. Y. (1987). Marine fish osteology. A manual for archaeologists. Burnaby: Simon Fraser University Archaeological Press.

Clavel, B. (2001a). L'animal dans l'alimentation médiévale et moderne en France du Nord (XII-XVIle siècles). Revue archéologique de Picardie, numéro spécial, 19, 9-204. https://doi.org/10.3406/pica.2001.3065

Clavel, B. (2001b). Les restes animaux de latrines médiévales à Bourg-laReine (Hauts-de-Seine). Archéopages, 3, 12-19.

De Grossi Mazzorin, J., \& Frezza, A. M. (2000). Lo sfruttamento delle risorse fluviali di due indediemti veneti dell'Età del Bronzo: Canàr (VR) e Frattesina (RO). Atti del $2^{\circ}$ Convegno Nazionale di Archeozoologia, 241-250.

Desse, J., \& Desse-Berset, N. (1992). Pêches locales, côtières ou lointaines: le poisson au menu des parisiens du Grand Louvre, du $14^{\text {ème }}$ au $18^{\text {ème }}$ siècle. Anthropozoologica, 16, 119-126.

Desse-Berset, N. (1994). Les Poissons. Gallia Préhistoire, 36, 219-224. https://doi.org/10.3406/galip.1994.2122

Desse-Berset, N. (2011a). Discrimination of Acipenser sturio, Acipenser oxyrinchus and Acipenser naccarii by Morphology of Bones and Osteometry. In P. Williot, E. Rochard, N. Desse-Berset, F. Kirschbaum, 
\& J. Gessner (Eds.), Biology and conservation of the European sturgeon Acipenser Sturio L. 1758 (pp. 23-48). Berlin: Springer. https://doi.org/ 10.1007/978-3-642-20611-5_3

Desse-Berset, N. (2011b). Ancient sturgeon populations in France through archaeozoological remains, from prehistoric time until the eighteenth century. In P. Williot, E. Rochard, N. Desse-Berset, F. Kirschbaum, \& J. Gessner (Eds.), Biology and conservation of the European sturgeon Acipenser Sturio L. 1758 (pp. 91-115). Berlin: Springer. https://doi. org/10.1007/978-3-642-20611-5_7

Desse-Berset, N., \& Desse, J. (2000). Salsamenta, garum et autres préparations de poissons. Ce qu'en disent les os. Mélange de l'Ecole Française de Rome. Antiquité, 112, 73-97. https://doi.org/10.3406/mefr.2000.2116

Enghoff, I. (1994). Fishing in Denmark during the Ertebølle period. International Journal of Osteoarchaeology, 4, 65-96. https://doi.org/10.1002/ oa.1390040203

Galik, A., Haidvogl, G., Bartosiewicz, L., Guti, G., \& Jungwirth, M. (2015). Fish remains as a source to reconstruct long-term changes of fish communities in the Austrian and Hungarian Danube. Aquatic Sciences, 77, 337-354. https://doi.org/10.1007/s00027-015-0393-8

Ginella, F., Hüster Plogmann, H., \& Schibler, J. (2009). Archäozoologische Ergebnisse aus den julisch-claudischen Militärlagern des 1. Jhs. n. Chr. In M. Reddé (Ed.), Oedenburg. Les fouilles françaises, allemandes et suisses à Biesheim et Kunheim, Haut-Rhin, France. Volume 1: Les camps militaires julio-claudiens (pp. 369-394). Monographien des RömischGermanischen Zentralmuseums 79.

Guillaud, E., Cornette, R., \& Béarez, P. (2016). Is vertebral form a valid species-specific indicator for salmonids? The discrimination rate of trout and Atlantic salmon from archaeological to modern times. Journal of Archaeological Science, 65, 84-92. https://doi.org/10.1016/j. jas.2015.11.010

Hüster Plogmann, H. (1999). Die Fischreste. In J. Rychener (Ed.), Der römische Gutshof in Neftenbach (pp. 422-423, 457-463). Zurich: Monographien der Kantonsarchäologie Zürich 31.

Hüster Plogmann, H. (2003). Von Leckerbissen und Schädlingen-Die Untersuchung der Kleintierreste. In A. Hagendorn (Ed.), Zur Frühzeit von Vindonissa. Auswertung der Holzbauten der Grabung WindischBreite 1996-1998 (pp. 231-243). Veröffentlichungen der Gesellschaft pro Vindonissa, Band XVIII/1.

Hüster Plogmann, H. (2004). Fischfang und Kleintierbeute. Ergebnisse der Untersuchung aus den Schlämmproben. In S. Jacomet, U. Leuzinger, \& J. Schibler (Eds.), Die jungsteinzeitliche Seeufersiedlung Arbon-Bleiche 3 (pp. 253-276). Archäologie im Thurgau 12.

Hüster Plogmann, H., \& Häberle, S. (2017). Archäozoologische Schlämmreste aus den Schichten 13 und 14. In N. Bleicher, \& C. Harb (Eds.), Zürich-Parkhaus Opéra. Eine neolithische Feuchtbodenfundstelle, Band 3: Naturwissenschaftliche Analysen und Synthese. Zürich: Monographien der Kantonsarchäologie Zürich 50.

Hüster-Plogmann, H. (2006). Synthèse. In H. Hüster-Plogmann (Ed.), Fish und Fisher aus zwei Jahrtausenden. Eine fishereiwirtschaftliche Zeitreise durch di Nordwestschweiz (pp. 223-231). Römerstadt Augusta Raurica, Forshungen in Augst 39.

Hüster-Plogmann, H. (2007). Fish and fishing through 2000 years in Switzerland. In H. Hüster-Plogmann (Ed.), The role of fish in ancient time. Proceedings of the $13^{\text {th }}$ meeting of the ICAZ fish remains working group (pp. 119-127). Rahden: Verlag Marie Leidorf GmbH.

Jacquat, C., \& Studer, J. (1999). L'âge du Bronze, naturellement! Le monde végétal et animal à Hauterive-Champréveyres NE. Archéologie Suisse, $22,22-26$

Jones, A. K. G. (1988). Provisional remarks on fish remains from archaeological deposits at York. In P. Murphy, \& C. French (Eds.), The exploitation of wetlands. Symposia of the Association for Environmental Archaeology No. 7 (pp. 113-127). Oxford: BAR British Series 186.
Le Gall, O. (1984). L'exploitation de l'ichthyofaune par les paléolithiques. Quelques exemples. In N. Desse-Berset (Ed.), $2^{\text {èmes }}$ rencontres d'archéo-ichthyologie (pp. 89-112). Centre de Recherches Archéologiques, Notes et monographies techniques $n^{\circ} 16$. Paris: CNRS.

Lepiksaar, J. (1994). Introduction to osteology of fishes for paleozoologists. Unpublished document: Göteborg.

Libois, R. M., \& Hallet-Libois, C. (1988). Eléments pour l'identification des restes crâniens des poissons dulçaquicoles de Belgique et du nord de la France. 2-Cypriniformes. APDCA: Juan-les-Pins.

Libois, R. M., Hallet-Libois, C., \& Rosoux, R. (1987). Eléments pour l'identification des restes crâniens des poissons dulçaquicoles de Belgique et du nord de la France. 1-Anguilliformes, Gastérostéiformes, Cyprinodontiformes et Perciformes. Juan-les-Pins: APDCA.

Oueslati, T. (2013). Analyse ichtyoarchéologique de la place du poisson de mer dans les pratiques alimentaires romaines du Nord de la France. In M. Y. Daire, C. Dupont, A. Baudry, C. Billard, J. M. Large, L. Lespez, et al. (Eds.), Anciens peuplements littoraux et relations Homme/Milieu sur les côtes de l'Europe atlantique (pp. 535-544). Oxford: BAR International Series 2570.

Oueslati, T. (2017). Aller à la pêche au gros et produire du garum à l'époque romaine dans le nord de la Gaule. In R. G. Villaescusa, K. Schörle, F. Gayet, \& F. Rechin (Eds.), L'exploitation des ressources maritimes de l'Antiquité. Activités productives et organisation des territoires (pp. 41-56). Antibes: APDCA.

Porcher, J. P., \& Baglinière, J. L. (2011). Le Saumon atlantique. In P. Keith, H. Persat, E. Feunteun, \& J. Allardi (Eds.), Les poissons d'eau douce de France (pp. 394-397). Paris: Biotope-Muséum National d'Histoire Naturelle.

Proteau, J. P., Schlumberger, O., \& Élie, P. (2008). Le silure glane. Biologie, écologie, élevage. Versailles: Quae.

Putelat, O. (2016). Les ossements animaux. In C. Croutsch (Ed.), Erstein, Bas-Rhin, "Parc d'activités du Pays d'Erstein, tranche 2 ". Évolution d'un terroir entre la fin du llle et le début du le millénaire avant notre ère. Rapport de fouille préventive (Vol. 3) (pp. 40-110). Sélestat: Pôle d'Archéologie Interdépartemental Rhénan.

Putelat, O. (2018). Les ossements animaux. In P. Flotté (Ed.), StrasbourgKoenigshoffen, 8-20 route des Romains. Sélestat: Rapport Final d'Opération (fouille préventive). Archéologie Alsace.

Putelat, O., Borvon, A., \& Guizard, F. (in prep 2019). Les tribulations du silure glane (Silurus glanis Linnaeus 1758) dans les cours moyen et supérieur du bassin rhénan, de l'âge du Bronze à l'Époque moderne. In Hommage à Corinne Beck. Valenciennes: Presses Universitaires de Valenciennes.

Radu, V. (2005). Atlas for the identification of bony fish bones from archaeological sites. Studii de Preistorie, supplementum 1 (p. 77). Bucuresti: Contrast.

Reimer, P. J., Bard, E., Bayliss, A., Beck, J. W., Blackwell, P. G., Ramsey, C. B., ... van der Plicht, J. (2013). IntCal13 and Marine13 radiocarbon age calibration curves 0-50,000 years cal BP. Radiocarbon, 55, 1869-1887. https://doi.org/10.2458/azu_js_rc.55.16947

Sabatié, M. R., \& Baglinière, J. L. (2001). Ordre des Pétromyzontiformes. La Lamproie marine. La Lamproie de rivière. La Lamproie de Planer. In P. Keith, \& J. Allardi (Eds.), Atlas des poissons d'eau douce de France (pp. 94-103). Paris: Muséum National d'Histoire Naturelle.

Schlumberger, O., Sagliocco, M., \& Proteau, J. P. (2001). Biogéographie du Silure glane (Silurus glanis): causes hydrographiques, climatiques et anthropiques. Bulletin français de la pêche et de la Pisciculture, 357-360, 533-547. https://doi.org/10.1051/kmae:2001002

Smith, D. N. (2013). Defining an indicator package to allow identification of "cesspits" in the archaeological record. Journal of Archaeological Science, 40, 526-543. https://doi.org/10.1016/j.jas.2012.06.014 
Spillmann, C. J. (1989). Poissons d'eau douce. Faune de France 65. Fédération Française des Sociétés de Sciences Naturelles: Paris.

Studer, J. (2003). La consommation des poissons du lac de Neuchâtel: hier et aujourd'hui. Cybium, 27, 65-67.

Van Neer, W., \& Ervynck, A. (2003). Remains of traded fish in archaeological sites: Indicators of status, or bulk food? In S. J. O'Day, W. Van Neer, \& A. Ervynck (Eds.), Behavior behind bones. The zooarchaeology of ritual, religion, status and identity. Proceedings of the 9th Conference of the International Council of Archaeozoology (pp. 202-214). Oxford: Oxbow Books.

Van Neer, W., \& Ervynck, A. (2004). Apport de l'archéozoologie à la connaissance de l'exploitation de l'eau douce au Moyen Age et à I'Epoque Moderne en Belgique. In P. Benoit, F. Loridant, \& O. Mattéoni (Eds.), Pêche et pisciculture en eau douce: la rivière et l'étang au Moyen Age. Actes des 1ères Rencontres Internationales de Liessies (22 pp.). Conseil Général du Nord: Lille.

Van Neer, W., \& Ervynck, A. (2009). The Holocene occurrence of the European catfish Silurus glanis in Belgium: The archaeozoological evidence. Belgian Journal of Zoology, 139, 70-78.

Van Neer, W., Ervynck, A., \& Monsieur, P. (2010). Fish bones and amphorae: evidence for the production and consumption of salted fish products outside the Mediterranean region. Journal of Roman Archaeology, 23, 161-195. https://doi.org/10.1017/S104775940000235X
Van Neer, W., \& Ervynck, A. (1994). New data on fish remains from Belgian archaeological sites. In W. Van Neer (Ed.), Fish Exploitation in the Past. Proceedings of the 7th meeting of the ICAZ Fish Remains Working Group (pp. 217-229). Annales du Musée Royal de I'Afrique Centrale 274, Sciences Zoologiques: Tervuren.

Van Neer, W., \& Lentacker, A. (1996). Restes fauniques provenant de trois fosses d'aisances du Grognon à Namur (Xllème, XVème-XVlème et XVIlème siècles). In J. Plumier, \& M. H. Corbiau (Eds.), Actes de la quatrième Journée d'Archéologie Namuroise (pp. 89-104). Namur.

Van Neer, W., \& Pieters, M. (1997). Evidence for processing of flatfish at Raversijde, a Late Medieval coastal site in Belgium. Anthropozoologica, 25-26, 579-586.

Wouters, W., Muylaert, L., \& Van Neer, W. (2007). The distinction of isolated bones from plaice (Pleuronectes platessa), flounder (Platichthys flesus) and dab (Limanda limanda): a description of the diagnostic characters. Archaeofauna, 16, 33-95. 